\title{
Indigenous Virginia Digital Storytelling Project: A Creation Story
}

\author{
Kasey Jernigan ${ }^{1, *}$ and Beth Roach ${ }^{2}$ \\ 1 Departments of Anthropology and American Studies, University of Virginia, Charlottesville, VA 22904, USA \\ 2 Tribal Council, Nottoway Indian Tribe of Virginia, Capron, VA 23829, USA; bethroachgrants@gmail.com \\ * Correspondence: kj2wz@virginia.edu
}

\begin{abstract}
Indigenous ways of knowing and being are invested in creating and maintaining relationships, respectful and equitable exchange, and collective but particularistic knowledges that are practical, useful, and helpful in extending meaning-making within communities. In this paper, we describe the ways that university faculty and tribal citizens come together to build meaningful relations through storytelling and counter-mapping. Focusing on what is currently known as Virginia (and the surrounding regions more broadly), the project aims to center Indigenous-created accounts of places and spaces as being infused with stories, memories, and life to reveal living histories layered into the fabric of these lands and waters. This paper details the careful, enjoyable, and challenging-at-times processes of relation-building between a university and local tribal citizens (which continues to take shape) for this project to become the Indigenous Virginia Digital Storytelling Project.
\end{abstract}

Keywords: digital storytelling; Native American Indigenous Studies; relation-building

check for updates

Citation: Jernigan, Kasey, and Beth Roach. 2021. Indigenous Virginia

Digital Storytelling Project: A

Creation Story. Genealogy 5: 88.

https://doi.org/10.3390/

genealogy5040088

Received: 15 May 2021

Accepted: 30 September 2021

Published: 18 October 2021

Publisher's Note: MDPI stays neutral with regard to jurisdictional claims in published maps and institutional affiliations.

Copyright: (c) 2021 by the authors. Licensee MDPI, Basel, Switzerland. This article is an open access article distributed under the terms and conditions of the Creative Commons Attribution (CC BY) license (https:// creativecommons.org/licenses/by/ $4.0 /)$.

\section{Preface}

The authors would like to first recognize that the stories and beings of this work transcend time, space, and relatives, yet the design of this project took shape on the ancestral lands of the Monacan Indian Nation. As Indigenous authors (but not Monacan citizens), acknowledging the homelands of the Monacan People is about recognizing ancient relations of friendship, kinship, and alliance between our Nations, as well as declaring our commitments (to this land and people) to dismantling settler colonialism. We are working to rebuild and renew these relations and contribute by theorizing, conceiving of methods, and putting into practice these commitments to dismantling settler colonialism, the resurgence of Indigenous culture, and the return of Indigenous lands.

\section{Introduction}

Decolonization struggles across North and South America have increasingly adopted the discourse of Land Back as a movement that represents the reclamation of Indigenous people's political, economic, and spiritual relationships with land that has been stolen or ceded through good faith efforts amidst ongoing settler colonialism. Scholars at the Yellowhead Institute describe Land Back as a process of "imagining and breathing life into jurisdiction and consent-based relationships with industry and government that push back against the assimilation that has destroyed so many in Indigenous communities" (Pasternak et al. 2019, p. 60). Although the principles of Land Back have existed as long as Indigenous peoples have resisted colonialism, the movement has taken up an urgency in the past couple of years as activists collaborate with Black organizing movements to work towards dismantling and defunding white supremacist systems and structures (LANDBACK Manifesto n.d.). Land Back is indeed about the literal restoration of land to Indigenous peoples; however, it also encompasses much more. The Land Back Movement also represents the fight for the restoration of Indigenous relationships with the earth. It is about reclaiming not only space and place but the stories, memories, meaning, ceremony, 
and connections with and within space and place. It is within this framing of Land Back that this project is positioned, with a focus on making visible Indigenous knowledge frameworks and languages for understanding relationships to land and waters. Recognizing land and water as relatives with agency, animacy, and deserving of respect, nurturing, and protection (Watts 2013; Yazzie and Baldy 2018), the larger goal of this project is to use digital storytelling as a method to make visible Indigenous peoples' stories and relationships to spaces, places, and other beings (Lucchesi 2018).

Given that research restrictions were in place due to COVID-19, we were not able to fully launch the research project according to our original timeline. Rather than describing our project methods and findings (which have yet to be completed), we detail the project's creation story instead. Through sharing the creation story, we show that telling how the project "came to be" is an important methodological contribution that centers Indigenous epistemologies while also providing the space to acknowledge the significance and potential intersections of Indigenous Studies methods and theories within the academy. In this way then, the telling of the Indigenous Virginia Digital Storytelling Project's creation story aims to make visible the multiple forms of engagement that are necessary for a collaborative project to take shape, how this specific digital storytelling (DST) project is situated within the academic institution, as well as how tribes engage with it. It is our goal that this paper serves as a sort of spatial ordering that connects our relationships to place, space, each other and other beings, and the project. Moreover, we hope that by sharing the creation story of this project that readers may be challenged to (re)consider conceptualizations of what counts as theory, as research, as data, as analytical methods, or as a research paper.

\section{Making Connections, Building Relations}

\subsection{The Tour}

In August of 2019, the first author (Kasey Jernigan) attended the University of Virginia's (UVA) new faculty orientation, which included a specialized historical tour of Grounds, an inscribed UNESCO world heritage site. The tour is categorized as a specialty tour because it also includes other sites related to the university's legacies of slavery and discrimination, with particular places/mnemonics giving voice to the few known experiences of enslaved laborers involved in building and running this institution and thus (re)storying previously ignored spaces and places at UVA. The tour moved through many difficult topics marked on Grounds, topics that remain relevant today, including for example, the integration of Black students and women. While it was a remarkable tour in that UVA openly grapples with its complicated legacies, it fails to acknowledge the Indigenous peoples who were forcibly removed (in one way or another) so that the university could be built. By failing to recognize the Monacan Indian Nation (and other Indigenous peoples) that continue to reside on these lands and who have made innumerable contributions to this region and the university, Indigenous peoples become erased and are made invisible. It was because of the notable absence of Indigenous peoples and the limited knowledge about Indigenous peoples among tour guides and others that Kasey came up with the idea to explore and piece together a historiography of Indigenous and UVA relations that could be shared with University Guide Services to develop a specialty tour focusing on Indigenous peoples at UVA. This was first imagined in terms of a course for advanced undergraduates, with the idea that they would explore archives, collaborate with tribal research partners around oral histories, and draft a tour guide narrative of Indigenous and UVA relations. However, as the project began to take shape, it became clear that it was much larger than a course designed to produce a specialty tour. Thus, the Indigenous Virginia Digital Storytelling Project (as it has come to be known) began to take shape.

\subsection{Mohomony (The Natural Bridge): A Tale of Two Stories}

A few days after the new faculty orientation and tour of Grounds, Kasey shared her observations and ideas for the engaged course with colleagues involved in the Native American Indigenous Studies (NAIS) at UVA Working Group (NAIS@UVA). We were 
carpooling to an informal meeting (organized by Beth Roach, the second author) with a small group of tribal citizens to introduce ourselves, get to know them, begin to build relations, and work to create collaborative spaces for local Indigenous needs, desires, and futures. We met at The Natural Bridge (Figure 1) located in the southern end of the Shenandoah Valley. Standing at 215 feet tall, the Natural Bridge is a spectacular 90-feetlong dolomite and limestone arch that stretches over Cedar Creek. Beth chose this site as the meeting place for a number of reasons. First, the university faculty were intentional about meeting with tribal citizens on their lands, at their convenience; second, the Natural Bridge is a sacred site for the Monacan People and a National Historic Landmark, thus a meaningful site for meeting and building relationships; and third, one of the Monacan partners, Victoria Ferguson, is an interpreter at the Monacan Indian Village replica, and visiting with her there allowed for connections and conversations around meaningful Monacan ways of being.

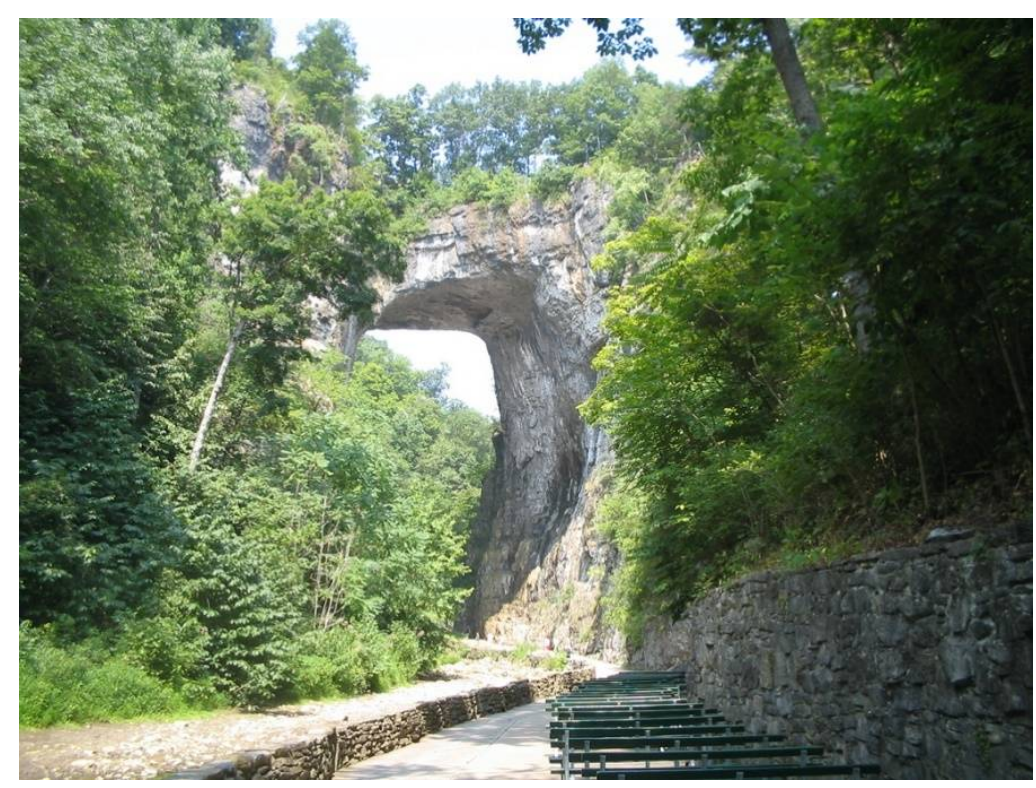

Figure 1. The Natural Bridge in Natural Bridge, VA. Source: Wikimedia Commons (2020).

As we were standing near the Natural Bridge, processing its profundity of power and medicine, Victoria shared with us the Natural Bridge's creation story, as told by the Monacans. "Mohomony" or the "Bridge of God" is sacred for its power and connection with Creator-it is a site where their ancestors not only survived but won an important victory. As we gazed up at the structure, viscerally feeling its beauty, medicine, and power, Victoria told us the story as she had learned it: Monacans had retreated from a battle and were running away from their enemies. As they ran through the forest to save their lives, they came to a cliff: a dead end. As their enemies neared, all seemed hopeless and the Monacans dropped to their knees, closed their eyes, and called upon Creator for help and guidance. When they opened their eyes, a gigantic stone bridge had appeared, providing a pathway across the previously impassable chasm. The women and children crossed safely to the other side as warriors fought off the enemy. This story has been passed down for generations and holds a sacred place in Monacan cosmology.

Consider the Monacan's creation story of "Mohomony" next to the most widely accepted scientific theory of the Natural Bridge's formation, which posits that the actual bridge is the remnant of the roof of an underground channel that diverted the waters of the upper portion of one water body into another, thereby forming Cedar Creek. Spencer (1968, p. 5) notes, "[t]he addition of these waters to the volume of the creek enabled it to more deeply incise its course, while the roof of the former conduit largely disintegrated and collapsed through erosion and weathering. Gradually the obvious elements of the 
underground channel disappeared until, at the present time, only the span of Natural Bridge preserves a portion of the original roof".

We offer these two vastly different creation stories of the same landmark-both theories yet to be "proven" - as a way to exemplify how Indigenous understandings of the world are often viewed as "mythic" or as "alternative" ways of understanding and interpreting our surroundings. The Monacan creation story of Mohomony is not recognized as a "real" event, or even a possible event—not in the same way that Spencer's (1968) account of the bridge's formation is recognized as "real" or possible. This experience meeting at Mohomony and learning the two creation stories (one creative and storied, the other informative and sterile in comparison) inspired the (re)storying space and place part of the project, centering local Indigenous knowledges of spaces and places.

Watts (2013) reminds us that colonization is not only an attack on peoples and their lands but that this attack is accomplished in part through intentional misrepresentations of Indigenous cosmologies. We are taught that our stories, our ways of knowing and being, are mythical and should be approached with scrutiny. We are taught to mistrust our own knowledges. Thus, it became clear that a project that seeks to make visible Indigenous places and spaces must not only engage with local Indigenous knowledges but center these knowledges. We must take seriously the stories that imbue land, water, plants, animals, and rocks with agency and animacy-that these other-than-human relatives are not only alive but are full of thought, will, and contemplation (Watts 2013). In these ways, then, it is perfectly conceivable that the stone willed itself into a bridge, working alongside its human relatives and in relation with Creator to provide a safe passage to the Monacans. The Indigenous Virginia DST project seeks to neither privilege one creation story over another; nor are we in search of a "truth". Rather, the project is interested in remembering these meaningful stories—stories that may help us to (re)imagine an otherwise world.

\subsection{The Archives}

A few months after the meeting at The Natural Bridge, the first author and colleagues from NAIS@UVA met with Teresa Pollak, Monacan Tribal Councilperson, who had been in touch with our working group. The goal of this meeting was to continue building relations and to create space for Monacan concerns within the university. At this meeting, we shared the idea of the course design in its early conception to obtain feedback from Teresa. She expressed that many tribal citizens were curious about Monacan-related materials housed at UVA and that this would be interesting, but she was concerned specifically that non-Indigenous students enrolled in the course might not be culturally sensitive towards the materials. In other words, she wanted to be sure that we knew what was in the archives before letting students have access.

On Indigenous Peoples' Day, a student from University Guide Services (UGS) contacted another NAIS@UVA member about creating a land acknowledgment for their tours (the same tour that started this project). The student was informed about the ongoing plans for this project, which at the time was still a course with the goal of creating a script for UGS. There was a noticeable new urgency — an exciting energy about NAIS—-that was taking shape across Grounds: Kasey (Choctaw) was newly hired to specifically focus on NAIS; new classes on the topics of NAIS were offered and in development; Beth visited several times to lecture and offer land-based learning; students were discovering the Land Back movement, Indigenous methods and theories, and beginning to recognize the invisibility of Indigenous peoples across the university. There was a palpable sense of momentum around NAIS, and it seemed necessary to run with it immediately. A small group of students worked with Professor David Edmunds, a member of NAIS@UVA and Director of Global Studies, whose work focuses on community engagement, to lay the groundwork for this project. At this time, it was just beginning to become clear that the archives/oral history course idea that stemmed from the faculty orientation tour was just the beginning. Indeed, it is important to note that although these events are presented in the order that 
they happen, this was anything but a linear process. The project revealed itself only after the authors reflected on the relationships between these events, stories, and meetings.

Serendipitously, the resident librarian at UVA, Hanni Nahabe Durand, reached out to Kasey just to connect with other Indigenous faculty. Hanni had recently arrived from Arizona for a three-year term and had been working on a special project for the past year: a survey of all archival materials housed in Special Collections which hold relevance to NAIS. As an Indigenous librarian with more than three decades of work with Indigenous communities in North and South America, she had embarked on this project in her free time, hoping to identify Indigenous voices and resources that could be useful to local tribes and NAIS scholars. She focused on 185 collections noted to include Native American content and examined 52 theses and dissertations on Indigenous themes, in an attempt to expand the volume of collections potentially relevant to Virginia Indians.

Spending more than $100 \mathrm{~h}$ of work over a 12-month period, she scrutinized bibliographic records, examined collections, and conducted background research on findings. Moreover, Hanni spent an additional $40 \mathrm{~h}$ in consultation with Virginian tribes and communities as a way to keep them informed of her findings. In the Executive Summary of her report, Hanni details the multiple ways that Indigenous peoples are erased, made invisible, and silenced, while illustrating the importance and necessity of a project that centers Indigenous peoples (Nahabe Durand 2020, p. 4):

"With one exception, indigenous voices are absent from the content of these archival holdings ... Collections belonging to the pre-contact and colonial periods make mention of Indigenous peoples as geographical reference points and as threats to life and property. Allusions to the successful amalgamation and erasure of Indigenous peoples are also prevalent, even in the James Logan Address, the lone indigenous voice among all materials reviewed, and seem to stand as self-validation that destiny was indeed manifest. For collections belonging to the 19th and 20th centuries, [state] Indians are mentioned almost exclusively in relation to the land from which they have been displaced. The [Native] Indian Tribe, which gave title to the only photograph of Indians found in this survey, are staged as backdrop to a group of white men that includes future [state] governor [redacted] - serving as graphic representation of who is telling these stories and of the innate value that such perspective is assumed to have... This Survey of Indigenous materials hoped to uncover stories that would stand as testament of the self-determination long denied to descendants of local Indigenous peoples. Instead, months of exploration yielded traces too faint to disentangle from that of the settler's gaze. This project's findings, much like Saidiya Hartman once declared, 'intend both to tell an impossible story and to amplify the impossibility of its telling.' We at the [University name] Library now have an opportunity to strengthen our foundation within the larger community by centering voices and exchanges long overdue, and thus contribute to making the impossible possible and the good great".

After Hanni shared this report, although disappointing, we were at least informed that there was not anything culturally sensitive in the archives (the Monacan's main concern about allowing students access to materials). Furthermore, it highlighted the extent to which Indigenous voices were missing, not just from the archives or the tours but in almost every possible way. This includes what we know about the land, the place and space here, and the surrounding areas. Much of this erasure can be traced to the Racial Integrity Act of 1924 and the Eugenics Movement that targeted "Indians" (and any other non-white individual) (Maillard 2006; Reilly and Shaw 1983; Sherman 1988) and reclassified all nonwhites as "Colored". Walter Plecker and fellow eugenicists aimed to purify the white race (Fiske 2004) through eliminating any evidence of "Indians". One of the ways they did this was through paper genocide: the act of modifying vital statistics records (i.e., births, marriages, deaths) or even destroying documentation of individual records that indicated "Indian". 
Thus, this project takes up the call of Hartman (2008, p. 11, as quoted by Nahabe Durand 2020, p. 4) to tell these impossible stories and to amplify the impossibility of their telling, to center Indigenous voices, knowledge, and experiences to strengthen our relationships with Indigenous Nations and communities, and to make the impossible possible. While the development of a multi-semester course is still part of the larger project, we have shifted our thinking from simply collecting and organizing archival materials for a historiography on Indigenous and UVA relations (which we have already begun and will continue to add to) to a long-term vision of an experiential course, eventually co-taught with Indigenous peoples and ultimately land-based. Secondly, we will conduct digital storytelling workshops over the next few months and in collaboration with our Indigenous research partners to articulate local Indigenous perspectives, knowledge, and stories of space, place, and histories. Because this is a space-, place-, and land-based project that centers Indigenous stories, we consider it a (counter) mapping project of sorts and selected the method of digital storytelling specifically to offer storytellers the option of storying space, place, and land in relation to each other, to other materials, and with multiple modalities. As digital stories, these can be collectively "mapped" to (re)imagine or remember these spaces, places, and lands. Together, all of this will combine to create a baseline of materials and knowledge-inclusive of both archives, materials and Indigenous knowledges.

\section{Digital Storytelling as Both Process and Product}

Digital Storytelling (DST) is an engaged and participatory research method that consists of 2-5-min visual narratives that synthesize images, video, audio, and text to create compelling accounts of experience and knowledge (Gubrium 2009; Lambert and Hessler 2018). In other words, digital stories are short films, told by one person, that combine still images, video, a voiceover recording, music, sound, and text. They are powerful and brief visual narratives that have the potential to uncover histories layered into the fabric of UVA, Charlottesville, and the surrounding areas (Gubrium et al. 2014). An integral component of this type of method is integrating voices that are often silenced or given less prioritization than others (Gubrium et al. 2014). It has the capacity to flip the paradigm and allow others to be mediamakers, craft their own narrative bodies of work to shed light on their lived realities, their spaces, places, histories, and ways of being. However, it also has the capacity to shift public conversations and can create a "narrative jolt" or an aligning moment (Gubrium et al. 2014) to create a pause in what may already be assumed as objective and universal knowledge of place. Thus, knowledge holders will participate in and create a type of counter mapping that challenges these assumptions; their knowledge of space, place, and events of these lands-both personal and collective - can create that aligning moment to (re)story the land, reminding us to perhaps really listen to or become acquainted with the land around us as it is interwoven with culture, story, and ceremony.

As a process-oriented practice, the act of creating digital stories is a process of knowledge production that is as rich and meaningful as the stories themselves. This DST project will allow for the opportunity to organize digital storytelling workshops that bring local Indigenous peoples together to share their stories as a way to transmit relevant knowledge while simultaneously creating new understandings of place, space, and histories. At the time of this publication, we have yet to begin the DST workshops, and instead describe our plans for the DST workshops, which we propose as four days long and incorporating both the archival materials collected for the course and people's own personal place- and spacebased stories. In this way, the workshops themselves will additionally serve as a space of generating knowledge where knowledge holders/storytellers collectively reflect, discuss, and participate in expressive writing, storytelling, and multi-sensory activities to engage in crafting their place-based stories (Gubrium 2009). For example, in story circles, storytellers will collectively workshop their stories to discuss the meanings, possible imagery, and potential ways to convey particular messages, and they will receive hands-on software and editing tutorials to help them finalize their story scripts. At the end of the workshops, they 
each retain a copy of their stories and access to the public database, StoryMap, that curates these stories.

As a participatory research method, DST includes tribal citizens not as research participants, but as research partners and knowledge holders/producers, thus shifting power dynamics inherent in traditional research methods. For Indigenous communities, participatory approaches, in general, allow new knowledge to emerge that is mediated by Indigenous perspectives and returns this knowledge to communities as Indigenously informed (Gubrium 2009). DST, in particular, increases tribal citizens' participation in research on local issues related to place by centering their experiences, understandings, and knowledge of historical and ongoing relations around place. By centering Indigenous voices, DST bolsters community building and collaboration between local tribes and the university, taking the partnership seriously (Gubrium 2009). DST as a process also builds community at the group level, both among the knowledge holders/producers (the workshop participants/storytellers) through the DST process but also across communities (i.e., across Virginia and North Carolina tribes) at large as it allows participants to create conversations with others about issues of common concern (Gubrium 2009).

Indigenous knowledge often comes from context-from relationships-rather than content. DST uses multi-sensorial techniques to imbue meaning but also to embrace the many ways of knowing spaces and places. So, it provides a modality for this contextualized "sensing" of place — a type of felt knowledge (Million 2009)—-that enables us to conceptualize place not just cognitively but through the many sensory channels of experience of relating (Gubrium et al. 2014). It allows for multiple forms of knowledge, of knowing a place. Particularly pertinent for this research, DST provides a source of information not readily offered through other resources (e.g., original documents, photos, maps, and other cultural materials). This approach reveals unspoken insights and embodied or visually articulated life-worlds not easily captured through traditional means (Gubrium et al. 2014). As Gubrium and colleagues (2014) note, digital stories are sense-making intimate objects with the capacity to serve as transformative artifacts of understanding, pushing the production of knowledge-and just what constitutes this knowledge-in new directions to inform our understandings of local Indigenous space, place, and histories.

\section{What Do We Do with All These Data?}

Cartography scholar Annita Lucchesi (2018, p. 13) argues that Indigenous or "ancestral mapping" is "any mapping or cartographic praxes developed by Indigenous ancestors who were not explicitly engaging with colonialism in their cartography". She and other scholars elaborate that this includes multiple forms of "mapping", such as tree carvings, beading, sewing Wampum belts, and oral stories to way-find and as spatial ordering (Lucchesi 2018, p. 11). McGurk and Caquard (2020, p. 4) note that mapping moved from being a mode of communication to a tool of dispossession, writing that "while Indigenous persons were 'mapping', which is a process-oriented activity indicative of an Indigenous way of seeing, Europeans were 'mapmaking', which is an object-focused activity that reflects a Eurocentric worldview" (McGurk and Caquard 2020). We build on these scholars' work to consider the concept of counter-mapping (Hunt and Stevenson 2017; Louis et al. 2012) using ArcGIS StoryMap (ArcGIS StoryMap n.d.; Kallaher and Gamble 2017), a web-based application that builds, publishes, and shares stories, as a repository for these materials: the archival materials and the digital stories produced during the DST workshops (De Master and Daniels 2019; Hart and Homsy 2020). The digital stories crafted by Indigenous peoples will be compiled using ArcGIS StoryMap (ArcGIS StoryMap n.d.) —along with the materials and outputs that are generated from the course- to weave Indigenous-created stories into our understandings of the spaces and places in and around UVA, Charlottesville, and the region more broadly. In other words, the StoryMap will link copious amounts of information in multiple formats-written materials, images, stories, and everyday practices. This living map will be unique in that it includes Virginian tribal citizens' personal digital stories and connections with place, with the capacity to (re)shape narratives about Indigenous/UVA 
relations, eugenics and the Racial Integrity Act of 1924, and landmarks and sites of importance. The StoryMap will grow each semester as our knowledge and networks expand and will serve as a map that reflects and guides actions that faculty and students can undertake with Indigenous research partners to transform the very relations we have researched, recorded, and centered. Moreover, the findings from these activities-the StoryMap, digital stories, materials, and the accompanying course-will be publicly available for more tribal citizens to view and submit their own stories. ${ }^{1}$

This project aims to produce a map that contains something very important: different ways of looking, knowing, and being. It will consider the humanity of those living on the landscape in relation to the land, waters, animals, and plants, expanding the experience of a place. It is a particularly Indigenous world that we live in, one infused with story, memory, and the many histories that created it. The StoryMap aims to convey particular relationships to place grounded in Indigenous knowledge and sustained presence on the land. These are the types of relationships that do not appear on modern maps, but they have the capacity to move us to examine our assumptions about what it is that makes up a place and the role that we play in these stories (Steinauer-Scudder 2018).

\section{Discussion}

The Indigenous Virginia DST project first revealed itself through absence. That is, the noticeable erasure and absence of Indigenous peoples at UVA during the specialized historical tour (or any of the multiple tours offered through University Guide Services) is what initiated the project. As a process-oriented project, we have attended to the careful, enjoyable, and challenging-at-times processes of relation-building between a university and local tribal citizens (which continues to take shape) for this project to become the Indigenous Virginia DST Project. Indeed, that is the point of this paper: to share how the project came to be. Yet, the project is already effecting change at UVA. The authors have been invited multiple times to discuss the project and tangential themes across departments and schools at UVA. Moreover, all university guides in training have since attended one of these talks; the university has collaborated with the Monacan Nation to craft a meaningful land acknowledgement; and plans are in place to develop an Indigenous-specific specialty tour. This is an important start, and there remains much more work to do.

Attentive to Cree scholar Ahenakew's (2016) concept of grafting - whereby Indigenous onto-epistemologies (Watts 2013) are transplanted from their naturally occurring contexts and implanted into (and thus interpreted through) non-Indigenous contexts (e.g., predominantly white academic/institutional research settings) - we heed his advice to include Indigenous knowledges and methodologies "with critical eyes wide open in relation to the agendas of institutions and to our own imperfect translations" (Ahenakew 2016, p. 337). This means, in part, foregoing the adoption of Indigenous knowledge and research for "quick fixes" or for diversity and inclusion efforts but instead as a way to include spaces of knowledge-production between Indigenous and non-Indigenous as sites of hope and possibility (Ahenakew 2016; Jones Brayboy and Maughan 2009). Moreover, we center Ahenakew's (2016) call for "a form of engagement that is not afraid of difficulties, complexities, impossibilities, and the limits of thinking ... " (p. 324) and work to make visible the many processes of engagement with Indigenous communities and university colleagues to center Indigenous ways of knowing and being in research. We outline these processes as a way to unveil the long and important road(s) to building relations with tribal nations, and the challenges that continue to appear as we produce knowledge that displaces the centrality of Western reasoning.

Author Contributions: Conceptualization, K.J. and B.R.; methodology, K.J.; writing—original draft preparation, K.J.; writing — review and editing, K.J. and B.R.; funding acquisition, K.J. All authors have read and agreed to the published version of the manuscript. 
Funding: This research was funded by the University of Virginia College of Arts \& Sciences Institute of the Humanities and Global Cultures and The Mapping Indigenous Worlds Lab at the University of Virginia.

Institutional Review Board Statement: Not applicable.

Informed Consent Statement: Not applicable.

Data Availability Statement: Not applicable.

Acknowledgments: The authors wish to acknowledge Teresa Pollak and Victoria Ferguson of the Monacan Indian Nation; Jim Igoe, David Edmunds, Hanni Durand, Sam Soloman, Zac Russell, Fernanda Yepez-Lopez, Anthonly Malabad, Blake Hesson, Charlotte Scharfenburg, and Paul Kay from the University of Virginia.

Conflicts of Interest: The authors declare no conflict of interest. The funders had no role in the design of the study; in the collection, analyses, or interpretation of data; in the writing of the manuscript, or in the decision to publish the results.

\section{Note}

1 StoryMap is easily accessible for sharing and displaying stories, but one limitation is its pricing. Therefore, this would be hosted by the university, and stories submitted outside of DST workshops would have to be collected and built into the StoryMap.

\section{References}

Ahenakew, Cash. 2016. Grafting Indigenous Ways of Knowing Onto Non-Indigenous Ways of Being The (Underestimated) Challenges of a Decolonial Imagination. International Review of Qualitative Research 9: 323-40. [CrossRef]

ArcGIS StoryMap. n.d. Environmental Systems Research Institute. Available online: https:/ /www.esri.com/en-us/arcgis/products/ arcgis-storymaps/overview (accessed on 14 May 2021).

De Master, Kathryn Teigen, and Jess Daniels. 2019. Desert wonderings: Reimagining food access mapping. Agriculture and Human Values 36: 241-56. [CrossRef]

Fiske, Warren. 2004. The Black \& White World of Walter Plecker. Style Weekly. Available online: https:/ /www.styleweekly.com/ richmond/the-black-and-white-world-of-walter-plecker/Content?oid=1381080 (accessed on 15 May 2021).

Gubrium, Aline. 2009. Digital storytelling: An emergent method for health promotion research and practice. Health Promotion Practice 10: 186. [CrossRef] [PubMed]

Gubrium, Aline C., Elizabeth L. Krause, and Kasey Jernigan. 2014. Strategic Authenticity and Voice: New Ways of Seeing and Being Seen as Young Mothers Through Digital Storytelling. Sexuality Research and Social Policy 11: 337-47. [CrossRef] [PubMed]

Hart, Siobhan M., and George C. Homsy. 2020. Stories from North of Main: Neighborhood Heritage Story Mapping. International Journal of Historical Archaeology 24: 950-68. [CrossRef]

Hartman, Saidiya. 2008. Venus in Two Acts. Small Axe: A Caribbean Journal of Criticism 12: 1-14. [CrossRef]

Hunt, Dallas, and Shaun A. Stevenson. 2017. Decolonizing geographies of power: Indigenous digital counter-mapping practices on turtle Island. Settler Colonial Studies 7: 372-92. [CrossRef]

Jones Brayboy, Bryan Mckinley, and Emma Maughan. 2009. Indigenous Knowledges and the Story of the Bean. Harvard Educational Review 79: 1-21. [CrossRef]

Kallaher, Amelia, and Alyson Gamble. 2017. GIS and the humanities: Presenting a path to digital scholarship with the Story Map app. College $\mathcal{E}$ Undergraduate Libraries 24: 559-73. [CrossRef]

Lambert, Joe, and Brooke Hessler. 2018. Digital Storytelling: Capturing Lives, Creating Community. Abingdon: Routledge.

LANDBACK Manifesto. n.d. LANDBACK. Available online: https:/ /landback.org/manifesto/ (accessed on 15 May 2021).

Louis, Renee Pualani, Jay T. Johnson, and Albertus Hadi Pramono. 2012. Introduction: Indigenous Cartographies and CounterMapping. Cartographica: The International Journal for Geographic Information and Geovisualization 47: 77-79. [CrossRef]

Lucchesi, Annita Hetoevèhotohke E. 2018. “Indians Don't Make Maps": Indigenous Cartographic Traditions and Innovations. American Indian Culture and Research Journal 42: 11-26. [CrossRef]

Maillard, Kevin Noble. 2006. The Pocahontas Exception: The Exemption of American Indian Ancestry from Racial Purity Law. Michigan Journal of Race and Law 12: 351-86. Available online: https://repository.law.umich.edu/mjrl/vol12/iss2/3 (accessed on 4 May 2021). [CrossRef]

McGurk, Thomas J., and Sébastien Caquard. 2020. To what extent can online mapping be decolonial? A journey throughout Indigenous cartography in Canada. The Canadian Geographer/Le Géographe Canadien 64: 49-64. [CrossRef]

Million, Dian. 2009. Felt Theory: An Indigenous Feminist Approach to Affect and History. Wicazo Sa Review 24: 53-76. [CrossRef]

Nahabe Durand, Hannivett. 2020. Final Report: Survey of Indigenous Materials in The Archives: Albert and Shirley Small Special Collections Library. Charlottesville: University of Virginia. 
Pasternak, Shiri, Hayden King, and Riley Yesno. 2019. Land Back: A Yellowhead Institute Red Paper. Toronto: Yellowhead Institute, Ryerson University, pp. 1-68. Available online: https://redpaper.yellowheadinstitute.org/wp-content/uploads/2019/10/redpaper-report-final.pdf (accessed on 8 May 2021).

Reilly, Philip, and Margery Shaw. 1983. The virginia racial integrity act revisited: The Plecker-Laughlin correspondence: 1928-1930. American Journal of Medical Genetics 16: 483-92. [CrossRef] [PubMed]

Sherman, Richard B. 1988. "The Last Stand": The Fight for Racial Integrity in Virginia in the 1920s. The Journal of Southern History 54: 69-92. [CrossRef]

Spencer, Edgar Winston. 1968. Geology of the Natural Bridge, Sugarloaf Mountain, Buchanan, and Arnold Valley Quadrangles, Virginia; Report of Investigations No. 13; Richmond: Virginia Division of Mineral Resources, Commonwealth of Virginia Department of Conservation and Economic Development, pp. 1-93. Available online: https://www.dmme.virginia.gov/commercedocs/RI_13 .pdf (accessed on 10 May 2021).

Steinauer-Scudder, Chelsea. 2018. Counter Mapping. Emergence Magazine. February 8. Available online: https://emergencemagazine. org/film/counter-mapping/ (accessed on 15 May 2021).

Watts, Vanessa. 2013. Indigenous Place-Thought and Agency Amongst Humans and Non Humans (First Woman and Sky Woman Go On a European World Tour!). Decolonization: Indigeneity, Education E Society 2: 20-34. Available online: https://jps.library. utoronto.ca/index.php/des/article/view/19145 (accessed on 13 May 2021).

Wikimedia Commons. 2020. The Free Media Repository. Natural Bridge. Available online: https://commons.wikimedia.org/w/index. php?title=File:Natural_Bridge.jpg\&oldid=454930578 (accessed on 11 May 2021).

Yazzie, Melanie, and Cutcha Risling Baldy. 2018. Introduction: Indigenous peoples and the politics of water. Decolonization: Indigeneity Education $\mathcal{E}$ Society 7: 1-18. Available online: https://jps.library.utoronto.ca/index.php/des/article/view/30378 (accessed on 10 May 2021). 